\title{
Przegląd wybranych narzędzi badawczych do oceny występowania oraz charakterystyki szumów usznych i nadwrażliwości słuchowej
}

\section{Tinnitus and hyperacusis assessment tools - an overview}

\author{
Joanna Rajchel ${ }^{1}$, Piotr Henryk Skarżyński ${ }^{2,3,4}$ \\ ${ }^{1}$ Międzyośrodkowe Studenckie Koło Naukowe przy Instytucie Fizjologii i Patologii Słuchu i Warszawskim \\ Uniwersytecie Medycznym, Warszawa \\ ${ }^{2}$ Instytut Fizjologii i Patologii Słuchu, Światowe Centrum Słuchu, Warszawa/Kajetany \\ ${ }^{3}$ Instytut Narządów Zmysłów, Kajetany \\ ${ }^{4}$ Warszawski Uniwersytet Medyczny, Zakład Niewydolności Serca i Rehabilitacji Kardiologicznej, Warszawa
}

Adres autora: Joanna Rajchel, Międzyośrodkowe Studenckie Koło Naukowe przy Instytucie Fizjologii i Patologii Słuchu i Warszawskim Uniwersytecie Medycznym, Warszawa, e-mail: aska.rajchel@gmail.com

\section{Streszczenie}

Obecnie wiele zagadnień dotyczących szumów usznych oraz nadwrażliwości słuchowej pozostaje niewyjaśnionych. Narzędziami pozwalającymi na lepsze ich poznanie mogą okazać się standaryzowane, powszechnie stosowane kwestionariusze. W literaturze anglojęzycznej można wyróżnić kilkanaście testów oceniających dokuczliwość szumów usznych. Mimo istniejących w Internecie tłumaczeń, żadne z zagranicznych narzędzi nie zostało zaadaptowane do języka i warunków polskich zgodnie z międzynarodowymi wytycznymi. Praca stanowi przegląd wybranych, krajowych i zagranicznych ankiet i kwestionariuszy, badających występowanie oraz charakterystykę szumów usznych i nadwrażliwości słuchowej. Każde narzędzie opisano ze szczególnym uwzględnieniem przeznaczenia, budowy, zawartości i sposobu oceny wyników oraz ich korelacji z wynikami innych testów opisywanych w literaturze przedmiotu.

Słowa kluczowe: kwestionariusze • szumy uszne • nadwrażliwość słuchowa

Abstract

At present, multiple issues concerning tinnitus and hyperacusis remain uncertain. Standardized and commonly used questionnaires provide a lot of support in better understanding of both issues. There are many research tools in English language that are used to assess tinnitus distress. None of them have been adapted and validated in accordance with global guidelines into the Polish language and culture. This paper presents an overview of foreign and Polish questionnaires used to assess tinnitus and hyperacusis. Every item was described taking into account the purpose, structure, content, methods of result evaluation and their correlation with other results of tests used in the literature.

Key words: assessment questionnaires • tinnitus • hyperacusis

\section{Wstęp}

Szumy uszne oraz nadwrażliwość słuchowa są zjawiskami występującymi powszechnie i mającymi poważne konsekwencje społeczne [1]. Dane polskie [2] wskazują, że 20\% osób dorosłych przynajmniej raz w życiu doświadczyło szumów usznych trwających dłużej niż 5 minut, natomiast prawie $5 \%$ zgłasza ich stałe występowanie. Badania zagraniczne prowadzone w latach 1999-2013 [3-7], w zależności od przyjętych metod pomiarowych, wykazały występowanie ciągłych szumów usznych u 7,9-17,8\% respondentów, przy czym około $4 \%$ osób oceniało je jako dokuczliwe. W niewielkim stopniu znane są do tej pory badania na temat występowania szumów usznych u dzieci. W Polsce zagadnieniem tym zajęli się Raj-Koziak i wsp., których badania [8] dowiodły, że aż 15244 (12,6\%) dzieci 7-letnich odczuwało szumy uszne, natomiast w grupie 12-latków odsetek ten wyniósł 16,6\%. W literaturze zagranicznej [9-13] częstość występowania szumów usznych określana jest od $12 \%$ do nawet $51 \%$; ich odczuwanie każdego dnia zgłasza $14 \%$ dzieci [11]. W związku z powszechnym występowaniem tego zjawiska stanowi ono wyzwanie dla lekarzy $i$ innych specjalistów w zakresie diagnostyki oraz rehabilitacji.

Mimo coraz większej wiedzy na temat możliwych przyczyn powstawania oraz miejsc generacji szumów usznych 
oraz związanej z nimi nadwrażliwości słuchowej [14-22], a także istnienia licznych terapii [23-32], wiele kwestii pozostaje nadal niejasnych. Ocena audiologiczna ma istotne znaczenie w diagnostyce pacjentów, jednakże wielu autorów wskazuje na brak znaczącej korelacji pomiędzy parametrami psychofizjologicznymi, m.in. wysokością, głośnością oraz poziomem maskowania szumów usznych, a ich dokuczliwością [33,34-37]. Chociaż wyniki kwestionariuszy poświęconych szumom usznym wykazują pomiędzy sobą różnorodne korelacje [35,38,39], nie przedstawiono do tej pory dowodu na istnienie jednego, w pełni skutecznego narzędzia nadającego się do diagnostyki i ewaluacji prowadzonych terapii. Testy oceniające dokuczliwość szumów usznych oraz sposoby radzenia sobie z następstwami tej dolegliwości dostępne są głównie w literaturze anglojęzycznej. W Polsce ankiety dotyczące szumów usznych wykorzystano głównie w badaniach przesiewowych [2]. Wybrane do przeglądu narzędzia badawcze $\mathrm{w}$ języku polskim oraz angielskim wraz z podziałem na docelowe grupy wiekowe przedstawione zostały, zgodnie z kolejnością występowania w tekście, $\mathrm{w}$ tabeli 1 .

Niniejsza praca stanowi opis narzędzi stosowanych w badaniach nad szumami usznymi, wykorzystywanych w celu: - zebrania wywiadu,

- oceny dokuczliwości,

- identyfikacji obszarów życia zakłóconych przez szumy uszne,

- ustalenia strategii radzenia sobie pacjenta ze swoją dolegliwością,

- różnicowania objawów szumów usznych oraz ubytku słuchu,

- oceny efektywności prowadzonych terapii.

W przeglądzie zawarto również opis jednego kwestionariusza przeznaczonego do badania nadwrażliwości słuchowej. Grupą docelową większości ankiet i kwestionariuszy są osoby dorosłe. Wyjątek stanowi Protokół diagnostyki szumów usznych przeznaczony specjalnie dla dzieci. Wykaz skrótów użytych w tekście, zgodnie z kolejnością ich występowania, przedstawiony został w tabeli 2 .

\section{Protokół diagnostyki szumów usznych u dzieci}

\section{A protocol of study for tinnitus in childhood}

Wprowadzenie. Protokół został stworzony przez Savastano w 2002 r. we Włoszech [40] w celu ustalenia etiologii oraz następstw występowania szumów usznych u dzieci. Zaproponowany przez autorkę model, po odpowiednim dopasowaniu do warunków społeczno-kulturowych, może przyczynić się do lepszego poznania tego zjawiska w grupie najmłodszych pacjentów. Savastano nie określa precyzyjnych granic wieku, podaje jedynie orientacyjny okres życia grupy docelowej - dzieciństwo (ang. childho$o d)$. W literaturze brak jest polskiej wersji protokołu. Czas potrzebny na jego przeprowadzenie nie został określony.

Budowa i zawartość protokołu. Protokół składa się z czterech głównych etapów. Pierwszym z nich jest zebranie szczegółowego wywiadu, związanego przede wszystkim $\mathrm{z}$ doznanymi w przeszłości urazami głowy oraz problemami otologicznymi. Drugi etap polega na ustaleniu braku lub potwierdzeniu występowania szumów usznych.
Dziecko pytane jest, czy doświadcza „hałasu” w uszach oraz czy jest w stanie podać jego dokładną lokalizację. Kolejnym etapem jest badanie otologiczne mające wykluczyć występowanie patologii w uszach. Ostatnia część protokołu jest najbardziej rozbudowana. Zawiera badanie audiologiczne oraz obszerne badania objawów charakterystycznych dla szumów usznych. Zawarte są tutaj pozycje takie jak: ogólna charakterystyka - wskazanie przez dziecko, jaki dźwięk najbardziej przypomina jego własne szumy uszne (m.in. czy jest to brzęczenie, szumienie, dzwonienie, uderzanie, świst), lateralizacja, opis wysokości, poziomu głośności oraz czasu trwania szumów usznych (przerywany/stały/występujący każdego dnia, trwający więcej/mniej niż 30 minut), stopień poirytowania oraz zaniepokojenia szumami usznymi. W procesie diagnostycznym autorka protokołu poleca także wykonanie badań audiologicznych, takich jak: audiometria tonalna, tympanometria $\mathrm{z}$ odruchem z mięśnia strzemiączkowego, badanie mózgowych potencjałów wywołanych, audiometryczne pomiary szumów usznych: wysokości oraz głośności, kompozycja spektralna, efektywność maskowania oraz badanie rezonansem magnetycznym. Ankieta nie zawiera pytań dotyczących występowania i charakterystyki nadwrażliwości słuchowej.

Ocena wyników. W artykule nie przedstawiono zasad punktacji poszczególnych etapów protokołu ani interpretacji wyniku końcowego. Nie zaprezentowano również kwalifikacji wyników do poszczególnych grup. Wartość MICD (ang. minimally important clinical difference), oznaczająca najmniejszą zmianę powstałą $\mathrm{w}$ wyniku prowadzonych terapii, którą pacjent uzna za istotną, nie została wyznaczona.

Występowanie związków $\mathrm{z}$ innymi testami. W przestudiowanej literaturze brak jest informacji na temat występowania związków między protokołem Savastano a innymi testami.

Wnioski. Protokół stworzony przez Savastano w swojej oryginalnej wersji nie jest przedstawiony w formie kwestionariusza. Ze względu na nieliczne badania dotyczące diagnostyki i leczenia szumów usznych u dzieci, można uznać go za istotną bazę i wzór do stworzenia takiego narzędzia w przyszłości. Protokół stanowi uporządkowany program najistotniejszych działań wchodzących w skład postępowania diagnostycznego. Oprócz podstawowej baterii testów audiologicznych uwzględnia subiektywne odczucia związane $\mathrm{z}$ występowaniem szumów usznych, mające znaczący wpływ na planowanie dalszych działań leczniczo-terapeutycznych.

\section{Kwestionariusze przeznaczone do badania szumów usznych u osób dorosłych}

\section{Kwestionariusze polskie}

\section{Ankieta epidemiologiczna występowania szumów usznych}

Wprowadzenie. Ankieta epidemiologiczna występowania szumów usznych została stworzona przez Bartnik i wsp. w 1997 r. [41] i jest jednym z bardzo niewielu narzędzi w języku polskim, oceniających występowanie szumów usznych u pacjentów dorosłych. Została wykorzystana do 
Tabela 1. Wybrane narzędzia badawcze do oceny szumów usznych oraz nadwrażliwości słuchowej w języku polskim, angielskim i francuskim wraz z podziałem na docelowe grupy wiekowe, podane zgodnie z kolejnością występowania w tekście

Table 1. Selected Polish, English and French tinnitus and hyperacusis assessment tools along with age groups classification, in the order of occurrence in the article

\begin{tabular}{|c|c|c|c|c|}
\hline Nazwa kwestionariusza & Autorzy i data publikacji & Główne zadania & Język & $\begin{array}{c}\text { Grupa } \\
\text { docelowa }\end{array}$ \\
\hline $\begin{array}{l}\text { A protocol of study for } \\
\text { tinnitus in childhood }\end{array}$ & Savastano 2002 & $\begin{array}{l}\text { Identyfikacja zjawisk związanych } \\
\text { z szumami usznymi u dzieci. }\end{array}$ & angielski & Dzieci \\
\hline $\begin{array}{l}\text { Ankieta epidemiologiczna } \\
\text { występowania szumów } \\
\text { usznych }\end{array}$ & Bartnik i wsp. 1997 & $\begin{array}{l}\text { Zebranie podstawowych informacji } \\
\text { dotyczących obecności i historii } \\
\text { szumów usznych. }\end{array}$ & polski & Dorośli \\
\hline $\begin{array}{l}\text { Ogólna dokuczliwość szumu } \\
\text { usznego }\end{array}$ & Kotyło i wsp. 2009 & $\begin{array}{l}\text { Ocena dokuczliwości szumów } \\
\text { usznych. }\end{array}$ & polski & Dorośli \\
\hline $\begin{array}{l}\text { Tinnitus Sample Case } \\
\text { History Questionnaire }\end{array}$ & Langguth i wsp. 2006 & $\begin{array}{l}\text { Zebranie kompleksowego wywiadu } \\
\text { dotyczącego występowania } \\
\text { i charakterystyki szumów usznych. }\end{array}$ & angielski & Dorośli \\
\hline $\begin{array}{l}\text { lowa Tinnitus Handicap } \\
\text { Questionnaire }\end{array}$ & Kuk i wsp. 1990 & $\begin{array}{l}\text { Rozpoznawanie stopnia uciążliwości } \\
\text { szumów usznych w życiu pacjenta } \\
\text { oraz monitorowanie postępów } \\
\text { prowadzonej terapii. }\end{array}$ & angielski & Dorośli \\
\hline $\begin{array}{l}\text { Tinnitus Reaction } \\
\text { Questionnaire }\end{array}$ & Wilson i wsp. 1991 & $\begin{array}{l}\text { Badanie wpływu szumów usznych } \\
\text { na styl życia, ogólne samopoczucie } \\
\text { oraz stan emocjonalny pacjenta. }\end{array}$ & angielski & Dorośli \\
\hline Tinnitus Questionnaire & Hallam 1996 & $\begin{array}{l}\text { Ustalenie szerokiego spektrum } \\
\text { dolegliwości psychologicznych } \\
\text { związanych z szumami usznymi. }\end{array}$ & angielski & Dorośli \\
\hline $\begin{array}{l}\text { Tinnitus Handicap } \\
\text { Inventory }\end{array}$ & Newman i wsp. 1996 & $\begin{array}{l}\text { Badanie trudności powstających } \\
\text { w życiu pacjenta na skutek } \\
\text { doświadczania przez niego szumów } \\
\text { usznych. }\end{array}$ & angielski & Dorośli \\
\hline $\begin{array}{l}\text { Tinnitus Cognition } \\
\text { Questionnaire }\end{array}$ & Wilson i Henry 1998 & $\begin{array}{l}\text { Ocena pozytywnych oraz } \\
\text { negatywnych aspektów } \\
\text { poznawczych związanych } \\
\text { z szumami usznymi. }\end{array}$ & angielski & Dorośli \\
\hline Tinnitus Functional Index & Meikle i wsp. 2011 & $\begin{array}{l}\text { Ocena dokuczliwości oraz } \\
\text { negatywnego wpływu szumów } \\
\text { usznych na życie pacjenta. }\end{array}$ & angielski & Dorośli \\
\hline $\begin{array}{l}\text { lowa Tinnitus Primary } \\
\text { Function Questionnaire }\end{array}$ & Tyler i wsp. 2014 & $\begin{array}{l}\text { Ocena podstawowych trudności } \\
\text { powodowanych w życiu pacjenta } \\
\text { przez szumy uszne. }\end{array}$ & angielski & Dorośli \\
\hline $\begin{array}{l}\text { Tinnitus and Hearing } \\
\text { Survey }\end{array}$ & Henry i wsp. 2015 & $\begin{array}{l}\text { Różnicowanie efektów związanych } \\
\text { z szumami usznymi i skutkami } \\
\text { utraty słuchu. }\end{array}$ & angielski & Dorośli \\
\hline $\begin{array}{l}\text { Tinnitus Retraining Therapy } \\
\text { Initial and Follow-up } \\
\text { Interview }\end{array}$ & Jastreboff I Jastreboff 1999 & $\begin{array}{l}\text { Ocena wpływu szumów usznych } \\
\text { i nadwrażliwości słuchowej na } \\
\text { życie pacjenta oraz ewaluacja } \\
\text { zmian występujących w trakcie i po } \\
\text { zakończeniu terapii. }\end{array}$ & angielski & Dorośli \\
\hline Hyperacusis Questionnaire & Khalfa i wsp. 2002 & $\begin{array}{l}\text { Ocena występowania } \\
\text { nadwrażliwości słuchowej oraz } \\
\text { próba identyfikacji obszarów przez } \\
\text { nią zaburzonych. }\end{array}$ & francuski & Dorośli \\
\hline
\end{tabular}

pierwszych w Polsce badań epidemiologicznych nad rozpowszechnieniem tej dolegliwości w naszym kraju [2]. Czas potrzebny na wypełnienie ankiety nie został określony.

Budowa i zawartość ankiety. Ankieta epidemiologiczna występowania szumów usznych składa się z 10 części.
Pierwsze cztery dotyczą podstawowych danych osobowych i występują w postaci pytań otwartych. Części 5., 6., 9. i 10. przedstawione są $\mathrm{w}$ formie pytań jednokrotnego wyboru z możliwymi odpowiedziami: „tak” lub „nie”. W części 7. pacjent ma za zadanie zaznaczyć dokuczliwość odczuwanych przez siebie szumów usznych w skali od 0 ( $s q$ 
Tabela 2. Wykaz skrótów użytych w tekście zgodnie z kolejnością ich występowania

Table 2. List of abbreviations used in the article, in the order of occurrence

\begin{tabular}{ll}
\hline \multicolumn{1}{c}{ Skrót } & \multicolumn{1}{c}{ Rozwinięcie } \\
\hline MICD & Minimally Important Clinical Difference \\
\hline GHQ-28 & General Health Questionnaire - 28 \\
\hline TQ & Tinnitus Questionnaire \\
\hline THQ & Tinnitus Handicap Questionnaire \\
\hline TRQ & Tinnitus Reaction Questionnaire \\
\hline TSCHQ & Tinnitus Sample Case History Questionnaire \\
\hline THI & Tinnitus Handicap Inventory \\
\hline TCQ & Tinnitus Cognition Questionnaire \\
\hline TFI & Tinnitus Functional Index \\
\hline BDI & Beck Depression Inventory \\
\hline TPFQ & Tinnitus Primary Function Questionnaire \\
\hline TAQ & Trait Anxiety Questionnaire \\
\hline PSIQ & Pittsburgh Sleep Quality Index \\
\hline THS & Tinnitus and Hearing Survey \\
\hline TRT-II & Tinnitus Retraining Therapy Initial Interview \\
\hline TRT-FI & Tinnitus Retraining Therapy Follow-up Interview \\
\hline HQ & Hyperacusis Questionnaire \\
\hline BAI & Beck Anxiety Inventory \\
\hline ULL & Uncomfortable Loudness Level \\
\hline
\end{tabular}

mi obojętne) do 10 (odchodzę od zmysłów). Część 8. występuje w postaci pytania wielokrotnego wyboru.

Pierwsze 4 pozycje Ankiety dotyczą ogólnych informacji na temat pacjenta: płci, roku urodzenia, miejsca zamieszkania: nazwy miejscowości i województwa oraz wykonywanego zawodu. Pytania części 5., 6., 9. i 10. dotyczą występowania:

- szumów usznych trwających dłużej niż 5 minut (do pytania dołączone jest wyjaśnienie terminu 'szumy uszne'),

- szumów usznych trwających bez przerwy,

- nadwrażliwości na dźwięki,

- problemów ze słuchem.

Pytanie wielokrotnego wyboru w części 8. dotyczy przyczyny pojawienia się szumów usznych u pacjenta, m.in. narażenia na hałas, słuchania głośnej muzyki, infekcji, urazu głowy, leków (prośba o doprecyzowanie, jakich konkretnie) lub innych powodów, które nie zostały uwzględnione w Ankiecie, a mogą zostać pisemnie zgłoszone przez pacjenta.

Ocena wyników. Nie przedstawiono zasad punktacji poszczególnych części Ankiety ani interpretacji wyniku końcowego. Nie zaprezentowano również kwalifikacji wyników do poszczególnych kategorii. Wartość MICD nie została wyznaczona.
Występowanie związków $\mathrm{z}$ innymi testami. W przestudiowanej literaturze brak jest informacji na temat występowania związków między opisywanym narzędziem a innymi testami.

Wnioski. Ankieta stworzona przez Bartnik i wsp. umożliwia zebranie podstawowego wywiadu dotyczącego obecności szumów usznych oraz współwystępowania innych dolegliwości, takich jak hyperacusis bądź uszkodzenie słuchu. Wiadomości te mogą być w warunkach badań przesiewowych bardzo przydatne podczas planowania dalszego postępowania diagnostycznego. Ankieta może służyć monitorowaniu występowania szumów usznych na danym obszarze (np. całego kraju lub poszczególnych województw) oraz być wykorzystywana do celów badań przesiewowych w gabinetach lekarzy rodzinnych i na oddziałach laryngologicznych. Nie pozwala jednak na identyfikację konkretnych zaburzeń spowodowanych szumami usznymi ani obszarów, w których występują. $Z$ tego powodu nie jest pomocna w stawianiu ostatecznej diagnozy, planowaniu terapii, ocenie osiąganych korzyści oraz strategii radzenia sobie z dolegliwością.

\section{Ogólna dokuczliwość szumu usznego}

Wprowadzenie. Ankieta Ogólna dokuczliwość szumu usznego została opublikowana przez Kotyło i wsp. w 2009 r. [42] w celu ustalenia dokuczliwości szumów usznych u pacjentów dorosłych zgłaszających się do Kliniki Audiologii i Foniatrii Instytutu Medycyny Pracy w Łodzi. Narzędzie zostało wykorzystane przez autorów do oceny efektów rehabilitacji wykorzystującej metodę habituacji. Czas potrzebny na wypełnienie ankiety nie został określony.

Budowa i zawartość ankiety. Narzędzie składa się z 6 pozycji. Oceniane sa w nim nastęujące zagadnienia: ogólna dokuczliwość szumów usznych, długość ich trwania w ciągu dnia, subiektywnie odczuwana przez pacjenta głośność, problemy związane z zasypianiem, napięcie nerwowe oraz problemy związane z pracą i koncentracją. Ankieta nie zawiera pytań dotyczących występowania i charakterystyki nadwrażliwości słuchowej.

Ocena wyników. Każde stwierdzenie oceniane jest w skali od 1 do 10, gdzie większa liczba oznacza rosnącą dokuczliwość szumów usznych. Maksymalny wynik wynosi 60 punktów. Szumy uszne uważa się za dokuczliwe, jeżeli w wyniku całkowitym pacjent osiągnie wynik 20 punktów i więcej lub ocena poszczególnej pozycji przekroczy 3 na 10 możliwych punktów. Kryteria te zostały oparte na wynikach osób nieposiadających szumów usznych z grupy kontrolnej. Autorzy nie zaproponowali podziału wyników na stopnie dokuczliwości szumów usznych ani kryteriów kwalifikacji do poszczególnych kategorii. Wartość MCID nie została wyznaczona.

Wystẹpowanie związków $\mathrm{z}$ innymi testami. W badaniach przeprowadzonych przez autorów [42] oprócz ankiety Ogólnej dokuczliwości szumu usznego wykorzystano standaryzowany kwestionariusz oceny ogólnego stanu zdrowia psychicznego General Health Questionnaire, zawierający dwadzieścia osiem pozycji (GHQ-28) [43]. GHQ-28 jest narzędziem przesiewowym i pozwala na wykrywanie zaburzeń takich jak depresja, niepokój i bezsenność, dolegliwości somatyczne czy problemy w funkcjonowaniu 
Tabela 3. Rodzaj informacji uzyskiwanych podczas przeprowadzania kwestionariusza TSCHQ oraz ich opis Table 3. Type of information obtained during TSCHQ administration with short item description

\begin{tabular}{|c|c|}
\hline Rodzaj uzyskiwanych informacji & Opis \\
\hline Wiadomości ogólne & $\begin{array}{l}\text { Imię i nazwisko pacjenta, data przeprowadzenia badania, data urodzenia, wiek, płeć, } \\
\text { „ręczność” (prawa/lewa/oburęczność), rodzinna historia choroby, początek dolegliwości } \\
\text { - nagły/stopniowy, czas pojawienia się szumów usznych po raz pierwszy, związek } \\
\text { pomiędzy ich pojawieniem się a wystąpieniem innych zdarzeń (np. urazu głowy czy } \\
\text { zmiany słyszenia), manifestacja szumów usznych w czasie - czy jest stały/przejściowy. }\end{array}$ \\
\hline Charakterystyka szumów usznych & $\begin{array}{l}\text { Pulsacja szumów usznych, miejsce odczuwania, głośność wyrażona w skali od } 1 \text { (bardzo } \\
\text { cichy) do } 100 \text { (bardzo głośny), wysokość, fluktuacje występowania, określenie szumów } \\
\text { usznych jako tony/szumy/cykanie świerszcza lub inne, wyznaczenie procentu czasu } \\
\text { w przeciągu ostatniego miesiąca, w którym pacjent był świadomy obecności szumów } \\
\text { usznych oraz procentu czasu, w którym pacjent z powodu świadomości szumów usznych } \\
\text { był zdenerwowany, poirytowany lub nieszczęśliwy. }\end{array}$ \\
\hline $\begin{array}{l}\text { Czynniki przydatne w planowaniu } \\
\text { terapii }\end{array}$ & $\begin{array}{l}\text { Liczba terapii, które pacjent przeszedł z powodu szumów usznych, zdolność } \\
\text { maskowania szumów usznych przez dźwięki otoczenia, pogarszanie się pod pływem } \\
\text { stresu czy głośnych dźwięków, wpływ drzemki w ciągu dnia na nasilenie dolegliwości, } \\
\text { występowanie związku pomiędzy snem a szumami usznymi, wpływ leków, } \\
\text { występowanie problemów ze słuchem, korzystanie z aparatów słuchowych, problemy } \\
\text { z tolerowaniem dźwięków normalnych dla innych osób, powodowanie bólu oraz } \\
\text { fizycznego dyskomfortu przez dźwięki, wpływ ruchów głowy i szyi na szumy uszne. }\end{array}$ \\
\hline Dolegliwości współwystępujące & $\begin{array}{l}\text { Bóle głowy, zawroty głowy pochodzenia obwodowego lub ośrodkowego, dysfunkcje } \\
\text { stawów skroniowo-żuchwowych, ból szyi, zespoły bólowe, terapia z powodu problemów } \\
\text { psychiatrycznych. }\end{array}$ \\
\hline
\end{tabular}

społecznym. Oceniając zależności pomiędzy wynikami GHQ-28 i ankiety Ogólnej dokuczliwości szumu usznego, autorzy uzyskali wysoką korelację pomiędzy stopniem uciążliwości szumów usznych a pogorszeniem stanu zdrowia psychicznego. Wykorzystując oba narzędzia do oceny postępów krótkotrwałej rehabilitacji metodą habituacji, w przeprowadzonych analizach nie wykazano statystycznie istotnych, korzystnych zmian, co - według Kotyło i wsp. - mogło mieć związek z początkowym etapem terapii.

Wnioski. Ankieta Ogólna dokuczliwość szumu usznego została stworzona na podstawie analizy kwestionariuszy wykorzystywanych przez zagranicznych autorów do oceny szumów usznych, m.in. TQ, THQ czy TRQ [44] tak, aby była prosta, łatwa do samodzielnego wypełniania oraz pozwalała na ocenę trudności najczęściej występujących u pacjentów posiadających szumy uszne. Za jej pomoca autorzy wykazali w swoich badaniach największe zaburzenia w zasypianiu, kontroli napięcia nerwowego oraz zdolności koncentracji. Według autorów ankieta Ogólna dokuczliwość szumu usznego wydaje się narzędziem czulszym w ocenie zmian występujących w trakcie terapii niż kwestionariusz GHQ-28, badający ogólny stan zdrowia psychicznego. Jednakże liczba obszarów życia pacjenta, które mogą być zaburzone, jest tutaj ograniczona do zaledwie kilku aspektów. Ankieta nie zawiera również pytań oceniających strategie radzenia sobie badanego ze swoją dolegliwością.

\section{Kwestionariusze zagraniczne}

\section{Tinnitus Sample Case History Questionnaire (TSCHQ)}

Wprowadzenie. TSCHQ został opracowany przez Langguth i wsp. w wyniku pierwszego spotkania TRI -Tinnitus Research Initiative w 2006 r. w Regensburgu [33]. Autorzy dostrzegli pilną potrzebę standaryzacji metod diagnostyki oraz oceny wyników terapii prowadzonych u pacjentów dorosłych z szumami usznymi. Aby to osiągnąć, stworzyli - na bazie wieloletnich doświadczeń, analiz oraz rozmów prowadzonych pomiędzy różnymi ośrodkami - projekt kwestionariusza pozwalającego na zebranie kompleksowego wywiadu dotyczącego tej dolegliwości. W literaturze brak jest polskiej wersji kwestionariusza. Czas potrzebny na jego przeprowadzenie nie został określony.

Budowa i zawartość kwestionariusza. TSCHQ składa się z 35. pozycji dotyczących czterech podstawowych obszarów związanych $\mathrm{z}$ występowaniem szumów usznych: wiadomości ogólnych, charakterystyki, czynników przydatnych w planowaniu terapii oraz dolegliwości współwystępujących. Rodzaje uzyskiwanych za pomocą TSCHQ informacji oraz ich opis przedstawione są w tabeli 3.

Ocena wyników. Autorzy nie przedstawili zasad dotyczących punktacji oraz oceny wyników kwestionariusza, jak również nie zaproponowali podziału wyników na stopnie uciążliwości szumów usznych ani kryteriów kwalifikacji do poszczególnych grup. Wartość MICD nie została wyznaczona.

Występowanie związków $z$ innymi testami. W przestudiowanej literaturze brak jest informacji na temat występowania związków między opisywanym narzędziem a innymi testami.

Wnioski. Zaproponowane w kwestionariuszu zagadnienia stanowią bazę, która może być przyjęta w oryginalnej wersji lub modyfikowana w zależności od potrzeb - forma i rodzaj pytań muszą uwzględniać różnice kulturowe, językowe, rozbieżności pomiędzy systemami opieki zdrowotnej, prowadzonymi bazami danych oraz istniejącymi algorytmami postępowania TSCHQ jest narzędziem szczególnie przydatnym przy zbieraniu wywiadu. 
Starannie przemyślany układ pytań wraz z wariantami odpowiedzi czytelnymi dla pacjentów i osób badających redukuje prawdopodobieństwo wystąpienia błędów wynikających z pominięcia istotnych kwestii w czasie procesu diagnostycznego. Kwestionariusz nie służy do identyfikowania obszarów zaburzonych przez szumy uszne, oceny strategii radzenia sobie pacjenta $\mathrm{z}$ dolegliwością oraz efektywności prowadzonych terapii.

\section{Iowa Tinnitus Handicap Questionnaire (THQ)}

Wprowadzenie. Iowa THQ został opracowany przez Kuka i wsp. w Stanach Zjednoczonych i opublikowany w 1990 r. [45]. Od tej pory stał się kwestionariuszem wykorzystywanym przez wielu klinicystów i badaczy. THQ został przetłumaczony na inne języki - m.in. język polski ${ }^{1}$. Brak jest jednak piśmiennictwa na temat adaptacji międzykulturowej przetłumaczonego kwestionariusza. Służy on do oceny trudności występujących w życiu pacjenta z powodu szumów usznych i identyfikowania obszarów, w których występują. Czas potrzebny na wypełnienie THQ nie został określony.

Budowa i zawartość kwestionariusza. Kwestionariusz składa się z 27 stwierdzeń tworzących 3 główne czynniki: 1. „Społeczne, emocjonalne i behawioralne skutki szumów usznych" (ang. Social, emotional and behavioral tinnitus effects), 2. "Szumy uszne i słyszenie” (ang. Tinnitus and hearing) oraz 3. „Zapatrywania na temat szumów usznych” (ang. Outlook on tinnitus). Pierwszy czynnik zawiera piętnaście stwierdzeń, drugi osiem, a trzeci składa się z czterech stwierdzeń. „Społeczne, emocjonalne i behawioralne skutki szumów usznych" dotyczą możliwości cieszenia się życiem, jakości relacji z innymi ludźmi, trudności w koncentracji oraz odpoczynku, uczucia zdenerwowania, niepewności, strachu, frustracji, zmęczenia, stopnia nasilenia depresji oraz problemów z zasypianiem spowodowanych szumami usznymi. Czynnik „Szumy uszne i słyszenie” skupia się na problemach, związanych m.in. z nadążaniem za konwersacją w czasie spotkań, unikaniu hałaśliwych sytuacji, trudnościach w lokalizacji źródła dźwięku, zaburzeniach rozumienia mowy podczas słuchania telewizji, obniżeniu umiejętności rozumienia mowy oraz niepokojem w sytuacjach wymagających aktywności społecznej. „Zapatrywania na temat szumów usznych” zawierają informacje na temat wsparcia uzyskiwanego od przyjaciół, poczucia pogorszenia się dolegliwości od momentu jej wystąpienia, racjonalnego podejścia do swojego stanu oraz przekonania o tym, że społeczeństwo nie posiada odpowiedniej wiedzy na temat szumów usznych. Kwestionariusz nie zawiera informacji na temat występowania i charakterystyki nadwrażliwości słuchowej.

Ocena wyników. Osoba wypełniająca kwestionariusz proszona jest o wpisanie w rubryce dotyczącej każdego stwierdzenia liczby z przedziału od 0 - co oznacza: zupetnie się nie zgadzam (ang. strongly disagree) do 100 - zgadzam się zupetnie (ang. strongly agree), wyrażającej stopień, w jakim badany identyfikuje się $\mathrm{z}$ przedstawionym zdaniem. Do kwestionariusza dołączona jest instrukcja dotycząca obliczania wyników - po jej zastosowaniu otrzymywany jest wynik z przedziału od 0 do 100; sumować można wszystkie pozycje jak również tylko te wchodzące w skład poszczególnych czynników. Im wyższy wynik, tym większych trudności związanych z szumami usznymi doświadcza pacjent w danym obszarze. Autorzy nie zaproponowali podziału wyników kwestionariusza na stopnie dokuczliwości ani kryteriów kwalifikacji do poszczególnych kategorii. Wartość MICD nie została wyznaczona.

Występowanie związków z innymi testami. Wyniki kwestionariusza THQ wykazują istotne statystycznie korelacje z wynikami innych narzędzi badawczych opisanych w pracy, takich jak: TRQ, TQ, THI, TCQ oraz TFI.

Wnioski. Według Kuka i wsp. THQ może być używany do porównywania trudności życiowych związanych z szumami usznymi, rozpoznawania właściwych obszarów ich występowania oraz monitorowania postępów prowadzonej terapii. Jego wyniki wykazują istotne statystycznie korelacje z wynikami skal oceniających jakość życia oraz nasilenie objawów depresyjnych, a także innych uznanych narzędzi służących do badania zjawiska. W kwestionariuszu brak jest pozycji odnoszących się do strategii radzenia sobie przez pacjenta $\mathrm{z}$ szumami usznymi.

\section{Tinnitus Reaction Questionnaire (TRQ)}

Wprowadzenie. TRQ został opublikowany w $1991 \mathrm{r}$. w Stanach Zjednoczonych przez Wilsona i wsp. [46] jako nowe narzędzie mające służyć do badania stopnia dokuczliwości szumów usznych. Kwestionariusz skupia się na kwestiach związanych z wpływem tej dolegliwości na styl życia, ogólne samopoczucie oraz stan emocjonalny pacjenta. Brak jest adaptacji międzykulturowej TRQ do warunków i języka polskiego. Czas potrzebny na jego wypełnienie nie został określony.

Budowa i zawartość kwestionariusza. TRQ zbudowany jest z 26. pozycji podzielonych na 4 części, określone przez autorów jako: „Ogólny dystres” (ang. General distress), „Zakłócenia” (ang. Interference), „Intensywność” (ang. Severity) oraz „Unikanie” (ang. Avoidance). Stwierdzenia zawarte w kwestionariuszu dotyczą następujących stanów i emocji odczuwanych przez pacjenta $z$ powodu szumów usznych: poczucia nieszczęścia, napięcia, poirytowania, złości, depresji, rozdrażnienia, zdezorientowania, cierpienia, bezradności, frustracji, rozpaczy, dystresu oraz paniki. W kwestionariuszu badane są również kwestie takie jak: możliwość doprowadzenia pacjenta do płaczu przez szumy uszne, brak zainteresowania wychodzeniem $\mathrm{z}$ domu, unikanie ciszy, głośnych sytuacji i aktywności społecznej, zakłócenia snu, czerpania radości z życia, zdolności do pracy, a także utrudnienia związane z koncentracją oraz odpoczynkiem. Pacjenci proszeni są o wskazanie, w jakim stopniu szumy uszne doprowadzają ich do szaleństwa, myśli samobójczych oraz rozpaczy na myśl o przyszłości. Brak jest pozycji dotyczących występowania i charakterystyki nadwrażliwości słuchowej.

Ocena wyników. Podczas wypełniania kwestionariusza wymagane jest zaznaczenie odpowiedzi najlepiej odpowiadającej aktualnemu stanowi pacjenta. Możliwymi do

\footnotetext{
1. Kwestionariusze dostępne są do pobrania bezpłatnie na stronie Uniwersytetu Medycznego Iowa pod adresem internetowym: http://www.medicine.uiowa.edu/oto/research/tinnitus/questionairres/.
} 
wyboru wariantami są: wcale nie (ang. not at all), niewiele czasu (ang. a little of a time), pewien czas (ang. some of the time), sporo czasu (ang. a good deal of the time) oraz prawie caly czas (ang. almost all of the time), punktowane odpowiednio jako 0, 1, 2, 3 i 4 punkty. Całkowity wynik kwestionariusza powstaje poprzez zsumowanie odpowiednich kolumn, mieszcząc się w przedziale 0-104. Autorzy nie zaproponowali podziału wyników kwestionariusza na stopnie uciążliwości ani kryteriów kwalifikacji do poszczególnych kategorii. Wartość MCID nie została wyznaczona.

Występowanie związków $\mathrm{z}$ innymi testami. Badania wykazały, że TRQ jest silnie skorelowany z innymi narzędziami służącymi do pomiaru dokuczliwości szumów usznych - THQ oraz THI.

Wnioski. Według autorów TRQ umożliwia określenie wpływu szumów usznych na codzienne funkcjonowanie pacjenta oraz nadaje się do mierzenia stopnia radzenia sobie pacjenta ze swoją dolegliwością. Wyniki kwestionariusza są silnie skorelowane $\mathrm{z}$ wynikami innych narzędzi służących do oceny dokuczliwości szumów usznych. Może on być stosowany jako jeden $\mathrm{z}$ testów pozwalających na analizę wyników zgodnie z zasadą cross-check.

\section{Tinnitus Questionnaire (TQ)}

Wprowadzenie. TQ został opracowany w latach 1981-1988 w Anglii przez Hallama, później był kilkakrotnie poprawiany i uaktualniany [47]. Głównym celem kwestionariusza jest ustalenie szerokiego spektrum dolegliwości psychologicznych związanych z szumami usznymi w celu złagodzenia ich dokuczliwości. TQ został przetłumaczony i zaadaptowany w wielu krajach - m.in. Niemczech, gdzie znalazł najszersze zastosowanie $[48,49]$, oraz Chinach [50]. Brak jest piśmiennictwa na temat adaptacji międzykulturowej kwestionariusza do warunków i języka polskiego. Wypełnienie TQ nie powinno zająć dłużej niż 5 do 15 minut, przy czym czas ten może wydłużać się w przypadku starszych pacjentów.

Budowa i zawartość kwestionariusza. Kwestionariusz TQ składa się z 52. stwierdzeń tworzących 5 głównych czynników, wykazujących między sobą istotne statystycznie korelacje: „Dystresu emocjonalnego” (ang. Emotional distress) - 19 stwierdzeń, „Utrudnień percepcji słuchowej” (ang. Auditory perceptual difficulties) oraz „Intruzywności” (ang. Intrusiveness) - po 7 stwierdzeń oraz „Zaburzeń snu” (ang. Sleep disturbance) i „Dolegliwości somatycznych” (ang. Somatic complaints) zawierających po 4 stwierdzenia. Pierwszy czynnik stanowi „Dystres emocjonalny” skupiający się na przekonaniach pacjenta dotyczących szumów usznych - obawach, prezentowanych wobec nich postawach oraz postrzeganiu wpływu dolegliwości na życie codzienne. Kolejnym czynnikiem są „Utrudnienia percepcji słuchowej” polegające na zaburzonej umiejętności wyraźnego słyszenia i rozumienia mowy przez pacjenta w codziennych sytuacjach: słuchaniu radia, oglądaniu telewizji, rozmowie przez telefon czy udziału w grupowej konwersacji. Trzeci czynnik - „Intruzywność” bada występowanie i stopień świadomości obecności szumów usznych u pacjenta oraz ich dokuczliwość. Czwarty czynnik składający się na TQ to „Zaburzenia snu”, dotyczące wpływu szumów usznych na sen - problemów związanych m.in. z zasypianiem oraz wybudzaniem się w nocy. Ostatni, piąty czynnik - „Dolegliwości somatyczne” określa związki pomiędzy występowaniem szumów usznych a bólem głowy, napięciem mięśni szyi i karku oraz możliwością odpoczynku. TQ nie zawiera informacji na temat współwystępowania i charakterystyki nadwrażliwości słuchowej.

Ocena wyników. Pacjenci proszeni są o określenie każdego stwierdzenia jako: prawdziwe, częściowo prawdziwe lub nieprawdziwe (ang. true, partly true or not true). W zależności od rodzaju stwierdzenia poszczególne odpowiedzi mogą być punktowane jako 0-1-2 lub 2-1-0. Jak widać, 5 czynników kwestionariusza zawiera 41 z 52 . pozycji wchodzących w skład TQ - i to one są sumowane w wyniku końcowym. Pozostałe stwierdzenia dotyczą przede wszystkim przekonań na temat istotności szumów usznych oraz możliwości radzenia sobie $\mathrm{z}$ nimi i zostały zawarte $\mathrm{w}$ kwestionariuszu ze względu na reprezentowaną przez nie istotną wartość kliniczną, m.in. podczas planowania terapii. Maksymalna liczba punktów, które pacjent może uzyskać, wynosi 82. Im wyższy wynik, tym większe prawdopodobieństwo występowania u pacjenta poważnych zaburzeń emocjonalnych. Autorzy nie zaproponowali podziału wyników kwestionariusza na stopnie uciążliwości ani kryteriów kwalifikacji do poszczególnych kategorii. Wartość MCID nie została wyznaczona.

Występowanie związków z innymi testami. Stwierdzono istotne statystycznie korelacje pomiędzy wynikami kwestionariusza TQ oraz kwestionariuszy THI, THQ i TRQ.

Wnioski. Prawie wszystkie stwierdzenia kwestionariusza TQ zawierają w sobie słowa „szumy uszne” lub „hałas w uszach”. Ma to zapewnić kierowanie się pacjentów podczas wybierania odpowiedzi jedynie efektami szumów usznych, nie zaś innych dolegliwości, co może okazać się przydatne w stawianiu wiarygodnej diagnozy. Kwestionariusz został pierwotnie stworzony do oceny efektów terapii kognitywnej, lecz znalazł swoje zastosowanie również w innych dziedzinach. Jego wyniki korelują z wynikami innych kwestionariuszy przeznaczonych do oceny obszarów zaburzonych przez szumy uszne oraz pomiaru strategii radzenia sobie $\mathrm{z}$ tą dolegliwością, takimi jak THI, TRQ oraz THQ.

\section{Tinnitus Handicap Inventory (THI)}

Wprowadzenie. Kwestionariusz THI został opracowany w Stanach Zjednoczonych w 1996 r. przez Newmana i wsp. [51]. Celem badaczy było stworzenie zwięzłego, łatwego w zastosowaniu i interpretacji kwestionariusza oceniającego problemy powstające w życiu pacjenta na skutek doświadczania szumów usznych. THI okazał się narzędziem przydatnym w praktyce klinicznej i uznanym w wielu krajach świata - m.in. Portugalii [52], Chinach [53], Turcji [54], Danii [55] oraz Włoszech [56]. Brak jest piśmiennictwa na temat adaptacji międzykulturowej kwestionariusza do warunków i języka polskiego. Czas potrzebny na wypełnienie THI nie został określony.

Budowa i zawartość kwestionariusza. THI składa się z 25. pytań podzielonych na 3 podskale: „Skalę funkcjonalną” (ang. Functional subscale) - zawierającą 11 pozycji, „Skalę emocjonalną" (ang. Emotional subscale) - 9 pozycji oraz 
„Skalę reakcji katastroficznych” (ang. Catastrophic response subscale) - 5 pozycji. „Skala funkcjonalna” dotyczy mentalnych, społecznych, zawodowych oraz fizycznych ograniczeń spowodowanych szumami usznymi. Zagadnienia w niej uwzględnione to: poczucie dezorientacji, nasilenie poirytowania i zmęczenia, wpływ stresu na dokuczliwość szumów usznych, a także trudności z czytaniem, koncentracją, wyraźnym słyszeniem, snem, cieszeniem się aktywnością społeczną oraz czerpaniem radości z życia. „Skala emocjonalna” pozwala określić emocje i stany towarzyszące występowaniu szumów usznych. Należą tutaj: złość, niepewność, frustracja, zmartwienie, rozdrażnienie, zaniepokojenie oraz obecność stanów depresyjnych. „Skala reakcji katastroficznych" ocenia reakcje prezentowane przez pacjenta w obliczu doświadczania szumów usznych: poczucie desperacji, zniewolenie, postrzeganie ich jako straszną chorobę, brak kontroli oraz przekonanie, że nie potrafi się ich dłużej znieść. THI nie zawiera informacji na temat współwystępowania i charakterystyki nadwrażliwości słuchowej.

Ocena wyników. Badany ma do wyboru trzy odpowiedzi na każde pytanie: tak, czasami, nie (ang. yes, sometimes, no), punktowane odpowiednio: 4, 2, 0. Po zsumowaniu odpowiedzi pacjenta badający może skorzystać z opracowanych przez Newmana i wsp. [57], a rozszerzonych i udoskonalonych przez McCombe'a i wsp. [58], następujących kategorii dokuczliwości szumów usznych: „nieznaczne”, „łagodne”, „umiarkowane”, „ciężkie”, „tragiczne”. Autorzy nie wyznaczyli wartości MCID.

Występowanie związków $\mathrm{z}$ innymi testami. Stwierdzono niskie korelacje pomiędzy wynikami THI a wysokością oraz głośnością szumu subiektywnie stwierdzanymi przez pacjentów. Wykazano istotne korelacje pomiędzy wynikami THQ i THI oraz pomiędzy wynikami BDI (Beck Depression Inventory) [59] a „Skalą emocjonalną". Kwestionariusz BDI jest powszechnie używanym narzędziem badawczym służącym do diagnozowania depresji. Ocena jego wyniku całkowitego zawiera podział nasilenia depresji na: brak występowania objawów depresji, depresję łagodną, umiarkowaną oraz ciężką.

Wnioski. Wspólnie z kwestionariuszami Dizziness Handicap Inventory [60] oraz Hearing Handicap Inventory for Adults [61] THI stanowi zestaw służący do szeroko zakrojonej diagnostyki chorób audiologiczno-otologicznych [57]. Stanowi narzędzie oceniające wpływ szumów usznych na odczuwane emocje, codzienne funkcjonowanie oraz postawy związane $\mathrm{z}$ doświadczaniem tej dolegliwości. Może służyć do oceny interwencji medycznych, chirurgicznych oraz wyników rehabilitacji. Mimo braku określenia wartości MCID wymienione przez McCombe’a i wsp. stopnie uciążliwości przydatne są w ocenie wyników terapii, kiedy skuteczność może objawiać się zmianą stopnia uciążliwości, np. z ciężkiego na umiarkowany.

\section{Tinnitus Cognition Questionnaire (TCQ)}

Wprowadzenie. TCQ został skonstruowany przez Wilsona i Henry w 1998 r. w Australii [62] jako narzędzie służące do oceny pozytywnych oraz negatywnych aspektów poznawczych związanych z szumami usznymi. Kwestionariusz może być używany jako narzędzie przesiewowe do identyfikowania pacjentów potrzebujących leczenia za pomocą terapii poznawczej oraz jako narzędzie pomiarowe - podczas badania zmian zachodzących w trakcie terapii. Brak jest piśmiennictwa na temat adaptacji międzykulturowej kwestionariusza do warunków i języka polskiego. Czas potrzebny na wypełnienie TCQ nie został określony.

Budowa i zawartość kwestionariusza. TCQ składa się z 26. stwierdzeń należących do dwóch czynników, zawierających po 13 pozycji: pozytywnych oraz negatywnych aspektów poznawczych prezentowanych przez pacjentów. Pierwszy czynnik - pozytywne aspekty poznawcze (ang. TCQ-positive) - opisuje następujące strategie radzenia sobie z szumami usznymi przez pacjenta:

- przekonanie, że istnieje możliwość cieszenia się życiem, a odwrócenie uwagi od szumów usznych zmniejszy ich dolegliwość,

- myślenie o tym, że pacjent nie jest jedyną osobą, której dotyczy ten problem, oraz że istnieją gorsze sytuacje w życiu niż doświadczenie szumów usznych,

- postanowienie, że mimo dokuczliwości szumów usznych nie będzie się nimi przejmował,

- wiarę w możliwość nauczenia się życia z szumami usznymi - nieważne, jak nieprzyjemne by były, pacjent będzie potrafił sobie z nimi radzić i nie pozwoli doprowadzić się do szaleństwa.

Drugi czynnik - negatywne aspekty poznawcze (ang. TCQ-negative) - dotyczy następujących przekonań pacjenta:

- pragnienia, aby szumy uszne zniknęły i pozwoliły na doświadczenie ciszy i spokoju (nie warto żyć, jeżeli będą stale obecne),

- żalu z powodu niezasłużonego cierpienia i braku pomocy ze strony innych ludzi,

- określania szumów usznych jako nieznośny, przytłaczający stan, powodujący problemy, których inni ludzie nie potrafią zrozumieć,

- braku szansy na zmniejszenie dokuczliwości szumów usznych w przyszłości.

Brak jest informacji dotyczących występowania i charakterystyki nadwrażliwości słuchowej.

Ocena wyników. Badany ma za zadanie określić, jak często w czasie występowania szumów usznych identyfikował się z poszczególnymi stwierdzeniami. Możliwe odpowiedzi są następujące: nigdy (ang. never), rzadko (ang. rarely), czasami (ang. occasionally), często (ang. frequently), bardzo często (ang. very frequently) punktowane odpowiednio: $0,1,2,3,4$ - dla aspektów negatywnych oraz 4, 3, 2, 1, 0 - dla aspektów pozytywnych. Wynik całkowity mieści się w przedziale od 0 do 104 . Im jest wyższy, tym większe prawdopodobieństwo, że pacjent będzie miał tendencję do zaangażowania $\mathrm{w}$ negatywne aspekty poznawcze. Autorzy nie zaproponowali podziału wyników kwestionariusza na stopnie uciążliwości szumów usznych ani kryteriów kwalifikacji do poszczególnych kategorii. Wartość MCID nie została wyznaczona.

Występowanie związków $z$ innymi testami. Według badań autorów, najsilniej z innymi narzędziami psychometrycznymi - TQ, THQ, TRQ oraz BDI - skorelowany jest wynik dotyczący obecności negatywnych aspektów poznawczych kwestionariusza TCQ. 
Wnioski. Kwestionariusz TCQ, oceniając występowanie pozytywnych i negatywnych aspektów poznawczych, służy do oceny efektywności prowadzonej terapii kognitywnej. Analizy statystyczne nie wykazały związku pomiędzy wynikami pochodzącymi z grupy pozytywnych oraz negatywnych aspektów poznawczych tego testu. Oznacza to, że wyższe wyniki dotyczące aspektów pozytywnych nie muszą oznaczać występowania niższych wyników aspektów negatywnych i odwrotnie. Fakt ten, łącznie z brakiem określenia stopni uciążliwości szumów usznych i kryteriów kwalifikujących, może powodować trudności w wyciąganiu wniosków i planowaniu działań terapeutycznych. TCQ nie ocenia również stopnia, w jakim pacjenci zaangażowani są $\mathrm{w}$ poszczególne aspekty poznawcze - w celu walidacji kwestionariusza autorzy zalecają w przyszłości dalsze badania. Ponadto za pomocą wyniku kwestionariusza nie można stwierdzić, które dokładnie obszary życia pacjenta są zaburzone. Wykazując korelacje z innymi narzędziami badawczymi oceniającymi dokuczliwość szumów usznych, TCQ może służyć jako uzupełnienie baterii testów wykorzystywanych w diagnozie i terapii zgodnie z zasadą cross-check. Nie powinien być jednak stosowany jako główne narzędzie badawcze.

\section{Tinnitus Functional Index (TFI)}

Wprowadzenie. TFI jest kwestionariuszem opublikowanym w 2012 r., skonstruowanym w wyniku współpracy wielu badaczy ze Stanów Zjednoczonych i Nowej Zelandii [63]. Celem opracowania TFI było stworzenie narzędzia umożliwiającego ocenę dokuczliwości szumów usznych oraz ich wpływu na życie pacjenta, pozwalającego na ewaluację zmian zachodzących w wyniku podjętego leczenia i rehabilitacji. Brak jest piśmiennictwa na temat adaptacji międzykulturowej kwestionariusza TFI do warunków i języka polskiego. Czas potrzebny na jego wypełnienie nie został określony.

Budowa i zawartość kwestionariusza. Wersja ostateczna kwestionariusza TFI składa się z 25. pozycji dotyczących 8. obszarów związanych z szumami usznymi: „Intruzywności” (ang. Intrusive), „Poczucia kontroli” (ang. Sense of control), "Funkcji poznawczych” (ang. Cognitive), „Snu” (ang. Sleep), „Słuchu” (ang. Auditory), „Odpoczynku” (ang. Relaxation), „Jakości życia” (ang. Quality of life) oraz „Emocji” (ang. Emotional). Każdemu obszarowi przyporządkowano po 3 pozycje (wyjątek: „Jakość życia” - 4 pozycje). Obszar „Intruzywność” obejmuje dokuczliwość szumów usznych - jak bardzo pacjent jest nimi poirytowany oraz jak ocenia ich natężenie. Obszar „Poczucie kontroli” dotyczy zdolności panowania nad swoją dolegliwością oraz umiejętności jej ignorowania. Zaburzenia poznawcze, takie jak trudności w koncentracji i zakłócona zdolność jasnego myślenia, ujęte są w „Funkcjach poznawczych”. Obszar "Sen” zawiera informacje na temat zakłóceń snu: trudności z zasypianiem, wysypianiem się oraz głębokim i spokojnym snem. W części poświęconej „Słuchowi” badane są zaburzenia słyszenia spowodowane szumami usznymi - możliwość wyraźnego słyszenia, rozumienia tego, co mówią inni ludzie, oraz podążania za konwersacją podczas spotkań w grupie. Szósty obszar: "Odpoczynek" dotyczy zakłócenia odpoczynku oraz możliwości cieszenia się „świętym spokojem”. „Jakość życia” określa pogorszenie się wybranych aspektów życia, takich jak radość $\mathrm{z}$ aktywności społecznej, utrzymywanie relacji z innymi ludźmi oraz wykonywanie pracy i codziennych obowiązków. Ostatnim obszarem TFI są „Emocje”, badające występowanie i nasilenie uczuć takich jak strach, zmartwienie, zdenerwowanie, a także stanów depresyjnych. Brak jest informacji na temat współwystępowania i charakterystyki nadwrażliwości słuchowej.

Ocena wyników. Przed rozpoczęciem wypełniania kwestionariusza pacjent zostaje poinformowany o tym, żeby w swoich odpowiedziach kierował się odczuciami dotyczącymi jedynie ubiegłego tygodnia. Wyznaczenie ściśle określonych ram czasowych jest nie tylko ułatwieniem dla wypełniającego, lecz pomaga także w ocenie aktualnych efektów terapii. Punktacja każdej pozycji TFI mieści się w przedziale od 0 do 10 . Wartości skrajne odpowiedzi, tzn. 0 oraz 10, posiadają opis słowny i stanowią punkty odniesienia w wyborze liczby najlepiej odpowiadającej aktualnym odczuciom pacjenta. Wynik całkowity mieści się w przedziale od 0 do 100 punktów - im jest wyższy, tym większe jest nasilenie dolegliwości. Dla celów klinicznych autorzy proponują następujący podział wyników: $<25$ punktów - szumy uszne uważane są za łagodne, niewymagające interwencji medycznej, 25-50 punktów - znaczne nasilenie szumów usznych, interwencja medyczna może okazać się konieczna, 50-100 punktów - nasilenie szumów usznych określane jest jako ciężkie, wymagające zaplanowania intensywnej terapii. Innym podziałem zaproponowanym przez autorów jest następująca kwalifikacja: 0-17 punktów - szumy uszne nie są uciążliwe, 18-31 punktów - szumy uszne stanowią niewielki problem, 32-53 punkty - szumy uszne stanowią umiarkowany problem, 54-72 punkty - szumy uszne stanowią duży problem, 73-100 punktów - szumy uszne są bardzo dużym problemem. Jako orientacyjną wartość MCID autorzy podali trzynastopunktową redukcję wyniku całkowitego lub jednego z ośmiu badanych obszarów.

Występowanie związków $z$ innymi testami. Kwestionariusz TFI został opracowany na podstawie 9 anglojęzycznych narzędzi powstałych w latach 1988-1999, m.in. TQ, THQ, TRQ oraz THI. Pytania w nim zawarte zostały wybrane na podstawie szczegółowych analiz statystycznych i cechują się najlepszą czułością.

Wnioski. Autorzy TFI podkreślają, że żadne z wcześniej opracowanych narzędzi badawczych dotyczących uciążliwości szumów usznych nie było bezpośrednio przeznaczone do zoptymalizowania pomiaru reakcji pacjenta na zmiany wynikające $\mathrm{z}$ działań leczniczo-terapeutycznych. $\mathrm{Z}$ tego powodu zdecydowali się na stworzenie specjalnie do tego celu zaprojektowanego kwestionariusza TFI. Przy jego wykorzystywaniu autorzy radzą korzystać także z jednego lub kilku dodatkowych kwestionariuszy pomiarowych, ze względu na zwiększenie prawdopodobieństwa uzyskania najbardziej miarodajnych wyników oraz możliwość ich sprawdzenia za pomocą metody cross-check.

\section{Iowa Tinnitus Primary Function Questionnaire (TPFQ)}

Wprowadzenie. TPFQ jest kwestionariuszem skonstruowanym przez Tylera i wsp. w 2003 r. [64] (jako wersja wstępna - Tinnitus Activities Questionnaire, później 
rozwinięty i opracowywany do wersji obecnej), zaprojektowanym specjalnie do oceny podstawowych skutków występowania szumów usznych. TPFQ powstał na bazie wcześniej istniejących kwestionariuszy, praktyki klinicznej autorów, rozmów z pacjentami oraz konsultacji $\mathrm{z}$ innymi specjalistami zajmującymi się szumami usznymi. TPFQ dostępny jest na stronie Uniwersytetu Iowa w dwóch wersjach przetłumaczonych na wiele języków - możemy pobrać go m.in. w języku polskim² ${ }^{2}$ Brak jest jednak piśmiennictwa na temat adaptacji międzykulturowej kwestionariusza do warunków i języka polskiego. Czas potrzebny na wypełnienie TPFQ nie został określony.

Budowa i zawartość kwestionariusza. TPFQ zawiera 20 pozycji podzielonych na 4 skale: „Koncentrację” (ang. Concentration), „Emocje” (ang. Emotion), „Słyszenie” (ang. Hearing) oraz „Sen” (ang. Sleep). Każda z wymienionych skal składa się z 5 pozycji. Skala „Koncentracja” zawiera stwierdzenia dotyczące trudności w skupieniu uwagi podczas trwania szumów usznych, np. w czasie czytania w cichym pomieszczeniu. Skala „Emocje” bada emocje i stany towarzyszące wystąpieniu szumów usznych, takie jak strach, frustracja i depresja. Trzecia skala - „Słyszenie” dotyczy wpływu zjawiska na jakość słyszenia dźwięków otoczenia i rozumienia mowy, a także różnicowania go ze skutkami współwystępującego uszkodzenia słuchu. Ostatnia skala - „Sen” - zawiera stwierdzenia dotyczące trudności z zasypianiem, niewyspania, wybudzania się ze snu oraz postaw prezentowanych względem tych dolegliwości. Brak jest informacji dotyczących współwystępowania i charakterystyki nadwrażliwości słuchowej.

TPFQ posiada swoją skróconą, 12-pozycyjną wersję [64], która powstała na bazie oryginału. Stwierdzenia w niej zawarte zostały wybrane na podstawie badań nad oryginalnym TPFQ i cechują się uzyskaniem najlepszych wyników w analizach statystycznych poszczególnych pozycji.

Ocena wyników. Pacjent proszony jest o wskazanie, w jakim stopniu zgadza się z każdym zdaniem, poprzez wybranie liczby z przedziału od 0 - kompletnie się nie zgadzam (ang. strongly disagree) do 100 - zgadzam się zupetnie (ang. strongly agree). Wyniki TPFQ można przedstawiać, wyciągając średnią zarówno z poszczególnych skal, jak i z całego kwestionariusza - wynik całkowity mieści się więc w przedziale od 0 do 100 , wskazując odpowiednio na nasilenie dolegliwości. Im wyższy wynik, tym większa dokuczliwość szumów usznych. Autorzy nie zaproponowali podziału wyników kwestionariusza na stopnie uciążliwości ani kryteriów kwalifikacji do poszczególnych kategorii. Wartość MCID nie została wyznaczona.

Występowanie związków $\mathrm{z}$ innymi testami. Tyler i wsp. przeprowadzili badania porównawcze pomiędzy TPFQ a THQ, BDI, Trait Anxiety Questionnaire (TAQ - służącym do oceny ogólnego stanu pacjentów i ich lęku) [65] oraz Pittsburgh Sleep Quality Index (PSQI - badającym jakość snu pacjentów) [66]. Wykazano wysokie korelacje pomiędzy wynikami TPFQ i THQ, wynikami skali „Emocje”, BDI i TAQ, a także skali „Sen” i PSQI.
Wnioski. Zdaniem autorów kwestionariusza skupienie się na zasadniczych skutkach szumów usznych pozwala na stworzenie narzędzia czułego w wykrywaniu zmian zachodzących podczas terapii i badań klinicznych. Wyników nie zakłócają zmienne związane z ogólną jakością życia pacjenta, mogące zmniejszać wrażliwość testu. TPFQ pozwala na ocenę zarówno wyniku zbiorczego, jak i każdej kategorii oddzielnie. Prowadzi to do określenia obszarów wymagających interwencji w formie terapii i/lub poradnictwa. W celu maksymalizacji skuteczności prowadzonych działań autorzy sugerują wykorzystanie dodatkowo innego stworzonego przez siebie kwestionariusza - THQ oraz analizę otrzymanych wyników zgodnie z zasadą cross-check. Skrócona, 12-pozycyjna wersja TPFQ może okazać się szczególnie przydatna w warunkach badań przesiewowych.

\section{Tinnitus and Hearing Survey (THS)}

Wprowadzenie. THS został opublikowany przez Henry'ego i wsp. w 2015 r. [67] jako nowe narzędzie przesiewowe służące do różnicowania efektów związanych z szumami usznymi i skutkami utraty słuchu. Kwestionariusz ma za zadanie pomóc w wyborze kierunku diagnostyki i terapii pacjenta. Brak jest jednak piśmiennictwa na temat adaptacji międzykulturowej kwestionariusza do warunków i języka polskiego. Czas potrzebny na wypełnienie THS nie został określony.

Budowa i zawartość. THS składa się z 10 stwierdzeń i podzielony jest na trzy główne części: A. „Szumy uszne” (ang. Tinnitus) - przynależą tutaj 4 stwierdzenia, B. „Słuch” (ang. Hearing) - 4 stwierdzenia oraz C. „Tolerancja dźwięku” (ang. Sound tolerance) - 2 stwierdzenia. Część „Szumy uszne" zawiera informacje odnoszące się do skutków szumów usznych, niepowikłanych przez utratę słuchu: zaburzenia snu, koncentracji podczas czytania, odpoczynku oraz umiejętności odwrócenia uwagi od szumów. Część „Słuch” dotyczy efektów związanych z utratą słuchu, niepowikłanych przez szumy uszne: trudności w rozumieniu mowy innych ludzi w głośnych i zatłoczonych pomieszczeniach, treści nadawanych w telewizji i filmów, konwersacji grupowych oraz głosu ludzi z łagodnym, miękkim głosem. Ostatnia część, „Tolerancja dźwięku”, bada stopień, w jakim dźwięki otoczenia wydają się pacjentowi zbyt głośne, oraz, w zależności od wersji kwestionariusza, zawiera m.in. prośbę o podanie przykładów nieprzyjemnych dźwięków lub wskazanie stopnia, w jakim rozmowa w gronie 5-10 osób jest dla badanego za głośna. Wybór wersji zależy od celu badania.

Ocena wyników. Wszystkie przedstawione w kwestionariuszu stwierdzenia rozpatrywane są $\mathrm{w}$ przedziale czasowym dotyczącym wyłącznie ubiegłego tygodnia - celem jest uzyskanie informacji na temat aktualnego stanu pacjenta, nie zaś całej historii związanej z szumami usznymi (która może trwać nawet kilkanaście/kilkadziesiąt lat). Możliwe odpowiedzi wyglądają następująco: nie, nie jest to dla mnie problemem (ang. no, not a problem), tak, jest to maty problem (ang. yes, a small problem), tak, jest to umiarkowany problem (ang. yes, a moderate problem), tak,

\footnotetext{
2. Kwestionariusze dostępne są do pobrania bezpłatnie na stronie Uniwersytetu Medycznego Iowa pod adresem internetowym:

http://www.medicine.uiowa.edu/oto/research/tinnitus/questionairres/.
} 
jest to duzy problem (ang. yes, a big problem) i tak, jest to bardzo duży problem (ang. yes, a very big problem), punktowane odpowiednio: $0,1,2,3,4$. Im wyższy wynik w jednej części, a niższy w drugiej, tym większe prawdopodobieństwo osiągnięcia korzyści z ukierunkowania podejmowanych działań właśnie na nią. Część C ma na celu sprawdzenie przede wszystkim występowania zjawiska $h y$ peracusis i jego przybliżonego nasilenia. Do wyników tej części należy podchodzić z dystansem, gdyż jej zawartość może wywoływać u niektórych osób dezorientację. Autorzy nie zaproponowali podziału wyników kwestionariusza na stopnie uciążliwości szumów lub utraty słuchu. Wartość MCID nie została wyznaczona.

Występowanie związków $z$ innymi testami. Wykazano, że wyniki części THS związanej z szumami usznymi (A - Tinnitus) korelują $\mathrm{z}$ wynikami walidowanego kwestionariusza THI.

Wnioski. Istotnym zadaniem stojącym przed audiologiem jest rozpoznanie, $\mathrm{w}$ jakim stopniu dolegliwości przypisywane przez pacjenta szumom usznym związane są z współwystępującym uszkodzeniem słuchu. Analizy statystyczne wyników THS wykazały, że podpunkty A i B mierzą dwa różne zjawiska i $\mathrm{z}$ tego powodu cel obrany przez badaczy został osiągnięty - kwestionariusz potrafi wskazać, która $\mathrm{z}$ dolegliwości stanowi dla pacjenta większy problem. Kwestionariusz TSH jest narzędziem przydatnym w podejmowaniu decyzji o zasadności interwencji medycznej związanej konkretnie z szumami usznymi. Jeżeli jej podjęcie jest konieczne, narzędziem polecanym przez autorów THS do badania wyników prowadzonej terapii jest TFI. TSH nie może być postrzegany jako zamiennik szczegółowego wywiadu oraz historii choroby. Jest kwestionariuszem przesiewowym, który pozwala w szybki sposób różnicować objawy związane z szumami usznymi i utratą słuchu, a dzięki temu pomaga w wyborze kierunku prowadzonej terapii.

\section{Tinnitus Retraining Therapy Initial and Follow-up Interview (TRT-II and TRT-FI) ${ }^{3}$}

Wprowadzenie. TRT Initial and Follow-up Interview został opracowany przez Jastreboffa i Jastreboff w Stanach Zjednoczonych [68]. Kwestionariusz ocenia wpływ szumów usznych oraz nadwrażliwości słuchowej na życie pacjenta. Służy do obserwacji zmian pojawiających się w trakcie trwania terapii habituacyjnej. TRT II i FI nadają się, po wprowadzeniu minimalnych zmian, do zastosowania we wszystkich krajach świata. W celu standaryzacji metod przeprowadzania kwestionariuszy wśród pacjentów, w latach 2002-2003 powstał przewodnik dotyczący ich stosowania $[69,70]$. Jest on pomocny przy uzyskiwaniu niezbędnych informacji do planowania odpowiedniego leczenia opartego na neurofizjologicznym modelu powstawania szumów usznych $[24,30]$. Brak jest piśmiennictwa na temat adaptacji międzykulturowej kwestionariusza do warunków i języka polskiego. Czas potrzebny na wypełnienie TRT-II oraz TRT-FI nie został określony.

Budowa i zawartość kwestionariusza. TRT-II składa się z 36 pozycji podzielonych na 3 główne części: 1. „Szumy uszne” (ang. Tinnitus) - 18 pozycji, 2. „Tolerancję dźwięku” (ang. Sound tolerance) - 12 pozycji, 3. „Słyszenie” (ang. Hearing) - 2 pozycje oraz część dotyczącą „Zaszeregowania dolegliwości" (ang. Ranking problems) - 3 pozycje odnoszące się do punktów 1, 2 oraz 3. TRT-FI stanowi skróconą, 28-pozycyjną wersję TRT-II - pominięte są w nim zagadnienia nieistotne w ocenie postępów terapii na kolejnych wizytach kontrolnych [68]. Przed przystąpieniem do wypełniania kwestionariusza konieczne jest wykonanie pełnej oceny audiologicznej i otologicznej w celu wykluczenia schorzeń uniemożliwiających wzięcie udziału w terapii [24]. Istotne jest również uzyskanie zgody od pacjenta na leczenie, które może trwać od 1 roku do 2 lat [70]. Jeżeli wszystkie warunki zostaną spełnione, w celu zakwalifikowania pacjenta do terapii wypełniany jest kwestionariusz TRT-II. Przeprowadzany jest ustnie przez osobę badającą, $\mathrm{z}$ uwzględnieniem szczegółowego opisu każdego z poruszanych zagadnień.

Zawartość każdej części kwestionariusza TRT-II została przedstawiona w tabeli 4 .

Kwestie, które zostały pominięte w TRT-FI, to przede wszystkim podstawowe informacje dotyczące szumów usznych, takie jak lokalizacja czy moment wystąpienia dolegliwości. Część z pytań została przeformułowana tak, aby maksymalnie skupić się na detekcji zmian w procesie prowadzonej terapii. W kwestionariuszu umieszczono nowe zagadnienia dotyczące zadowolenia pacjenta $\mathrm{z}$ udziału $\mathrm{w}$ terapii oraz przydatności urządzeń pomocniczych wykorzystywanych w jej trakcie.

Ocena wyników. Nie przedstawiono zasad punktacji poszczególnych etapów wywiadu ani interpretacji wyniku końcowego. Nie zaprezentowano również kwalifikacji wyników do poszczególnych kategorii. Wartość MCID nie została wyznaczona.

Występowanie związków $\mathrm{z}$ innymi testami. W przestudiowanej literaturze brak jest informacji na temat występowania związków między omawianymi kwestionariuszami a innymi testami.

Wnioski. Kwestionariusze TRT-II oraz TRT-FI umożliwiają szczegółowe zbadanie występowania szumów usznych, obniżonej tolerancji na dźwięki, ubytku słuchu oraz określenie ich wpływu na życie pacjenta. Zaproponowana forma pozwala na zwiększenie świadomości pacjenta na temat odmienności przedstawianych zjawisk i opracowanie - wspólnie ze specjalistą prowadzącym leczenie - optymalnego planu terapii. Chociaż TRT-II oraz TRT-FI zostały zaprojektowane specjalnie z myślą o terapii metodą TRT, nadają się również do oceny innych metod terapii [70]. Ich ewaluacja powinna zostać przeprowadzona za pomocą analiz statystycznych, określających rzetelność i wiarygodność wykonywanych badań.

\section{Kwestionariusz przeznaczony do badania nadwrażliwości słuchowej u osób dorosłych}

\section{Hyperacusis Questionnaire (HQ)}

Wprowadzenie. HQ został stworzony i opublikowany przez Khalfa i wsp. w 2002 r. we Francji [71]. Stanowi 
Tabela 4. Części wchodzące w skład TRT-Initial Interview oraz poruszane w nich zagadnienia Table 4. Parts of TRT-Initial Interview with brief item description

\begin{tabular}{|c|c|}
\hline Nazwa grupy & Poruszane zagadnienia \\
\hline Szumy uszne & $\begin{array}{l}\text { Lokalizacja, obecność szumów usznych: stałe/przejściowe, fluktuacja głośności, początek } \\
\text { wystąpienia, najbardziej nieznośny dźwięk występujący w szumach usznych, zmiana uciążliwości } \\
\text { w czasie, wpływ innych dźwięków na nasilenie dolegliwości, używanie zatyczek do uszu } \\
\text { lub nauszników, otrzymywane terapie (w tym stosowane na własną rękę terapie medycyny } \\
\text { alternatywnej), wpływ szumów usznych na aktywności dnia codziennego, m.in. koncentrację, sen, } \\
\text { odpoczynek, czytanie, pracę, aktywność społeczną, procent czasu, w którym pacjent jest świadomy } \\
\text { swoich szumów usznych oraz rozdrażniony, nieszczęśliwy lub poirytowany, ocena w skali } 1 \text { do } 10 \\
\text { głośności szumów usznych oraz rozdrażnienia z ich powodu, dodatkowe uwagi pacjenta na temat } \\
\text { swojej dolegliwości. }\end{array}$ \\
\hline Tolerancja dźwięku & $\begin{array}{l}\text { Zmniejszona tolerancja na dźwięki (jeżeli pacjent zaprzeczy występowaniu tego zjawiska, od razu } \\
\text { przechodzi się do grupy Styszenie), ból/fizyczny dyskomfort powodowany przez dźwięki, zmiana } \\
\text { tolerancji na dźwięki w czasie, wpływ innych dźwięków na możliwość tolerancji dźwięku, udział } \\
\text { w terapii dotyczącej nadwrażliwości słuchowej, główny problem związany ze zmienioną tolerancją } \\
\text { na dźwięki, wpływ zmniejszonej tolerancji na dźwięki na aktywności życia codziennego, m.in. } \\
\text { udział w koncertach, robienie zakupów, oglądanie filmów, prowadzenie samochodu, opieka nad } \\
\text { dziećmi, ocena w skali } 1 \text { do } 10 \text { (im wyższa liczba, tym większy stopień dolegliwości): uciążliwości } \\
\text { związanej ze zmniejszoną tolerancją na dźwięki, poirytowaniem z tego powodu, wpływu } \\
\text { zmienionej tolerancji na dźwięki na życie pacjenta. Ostatni element zawiera możliwość podania } \\
\text { przez pacjenta dodatkowych uwag na temat zmniejszonej tolerancji na dźwięki, które chciałby } \\
\text { zgłosić. }\end{array}$ \\
\hline Styszenie & Używanie aparatów słuchowych, wystąpienie kiedykolwiek rekomendacji odnośnie ich używania. \\
\hline Zaszeregowanie dolegliwości & $\begin{array}{l}\text { Ocena w skali } 1 \text { do } 10 \text { stopnia, w jakim szumy uszne, zmniejszona tolerancja na dźwięki oraz } \\
\text { słyszenie są dla pacjenta problemem. }\end{array}$ \\
\hline
\end{tabular}

narzędzie oceniające nadwrażliwość słuchową u pacjentów dorosłych. Brak jest piśmiennictwa na temat adaptacji międzykulturowej kwestionariusza do warunków i języka polskiego. Czas potrzebny na jego wypełnienie nie został określony.

Budowa i zawartość kwestionariusza. HQ składa się z dwóch części. Pierwsza z nich pozwala na uzyskanie podstawowych danych o pacjencie, takich jak: imię i nazwisko, płeć, wiek, zawód, miejsce zamieszkania, telefon kontaktowy, występowanie ekspozycji na hałas, obecność zmniejszonej tolerancji na dźwięki w porównaniu $\mathrm{z}$ latami ubiegłymi oraz problemów ze słuchem wraz $\mathrm{z}$ ich sprecyzowaniem. Część druga zawiera 14 pytań dotyczących trzech wymiarów życia: „Wymiaru koncentracji” (ang. Attentional dimenson) składającego się z 4 pytań, „Wymiaru społecznego" (ang. Social dimension) składającego się z 5 pytań oraz „Wymiaru emocji” (ang. Emotional dimension) składającego się z 4 pytań. „Wymiar koncentracji” bada występowanie zaburzeń koncentracji w obecności niechcianych dźwięków, umiejętność ignorowania hałasu otoczenia oraz stosowania nauszników i zatyczek do uszu $\mathrm{w}$ celu poradzenia sobie $\mathrm{z}$ problemem. $\mathrm{W}$ „Wymiarze społecznym" zawarte są pytania dotyczące wpływu nadwrażliwości słuchowej na społeczne funkcjonowanie pacjenta: trudności podczas rozmowy w głośnym otoczeniu, wrażliwości na hałas uliczny oraz rezygnacji $\mathrm{z}$ uczestnictwa w wydarzeniach towarzyskich ze względu na nadwrażliwość na dźwięki. Pytania dotyczące stresu i irytacji z powodu nadwrażliwości słuchowej, nasilenia dokuczliwości dźwięków w cichym środowisku, problemów z koncentracją pod koniec dnia w głośnym otoczeniu oraz zmniejszonej umiejętności koncentracji pod wpływem zmęczenia i stresu zawarte są w „Wymiarze emocji”. Kwestionariusz nie zawiera pozycji określających występowanie i charakterystykę szumów usznych.

Ocena wyników. Pytania zawarte w części drugiej kwestionariusza posiadają cztery warianty odpowiedzi: nie (ang. no), tak, sporadycznie (ang. yes, a little), tak, często (ang. yes, quite a lot) oraz tak, prawie zawsze (ang. yes, a lot) i są punktowane odpowiednio: 0, 1, 2 oraz 3 punkty. Wynik całkowity mieści się w przedziale $0-42$. Występowanie nadwrażliwości słuchowej stwierdza się, kiedy pacjent uzyska 28 punktów i więcej. Autorzy nie zaproponowali podziału wyników kwestionariusza na stopnie nasilenia nadwrażliwości słuchowej ani kryteriów kwalifikacji do poszczególnych kategorii. Wartość MCID nie została wyznaczona.

Występowanie związków $z$ innymi testami. Badania nad wynikami anglojęzycznej wersji HQ wśród pacjentów z szumami usznymi za pomocą kwestionariuszy THI, THQ, BDI, BAI (Beck Anxiety Inventory, wykorzystywanym do mierzenia stopnia nasilenia stanów lękowych u dzieci i osób dorosłych) wraz z wykonaniem badania ULL (ang. Uncomfortable Loudness Level - poziom dźwięku, który wydaje się pacjentowi niekomfortowy) zostały przeprowadzone przez Fackrell i wsp. [72]. Otrzymano umiarkowane korelacje pomiędzy wynikami HQ oraz wynikami innych kwestionariuszy. Zaobserwowano również rozbieżności pomiędzy wynikami HQ a badaniem ULL.

Wnioski. Mimo że analizy statystyczne opisane przez autorów HQ wykazały jego przydatność w ocenie nadwrażliwości słuchowej u osób dorosłych, to przeprowadzone niedawno szczegółowe badania Fackrell i wsp. [72] w populacji osób z szumami usznymi uwidoczniły istotne braki kwestionariusza. Zakwestionowano skład i strukturę HQ 
oraz kryterium różnicujące brak oraz obecność występowania nadwrażliwości słuchowej. Zarekomendowano dalsze badania nad stworzeniem narzędzia oceniającego występowanie tej dolegliwości, szczególnie w populacji osób z szumami usznymi.

\section{Podsumowanie}

Wyniki kwestionariuszy wykorzystywanych do badania szumów usznych i nadwrażliwości słuchowej wykazują pomiędzy sobą różnorodne korelacje $[35,38,39]$. Nie przedstawiono do tej pory dowodu na istnienie jednego, w pełni skutecznego narzędzia nadającego się do diagnostyki i ewaluacji prowadzonych terapii. Analizy wykorzystujące niektóre $z$ kwestionariuszy opisanych w niniejszej pracy świadczą o występowaniu istotnego związku pomiędzy ubytkiem słuchu, wiekiem, płcią oraz czasem trwania szumu usznego i nadwrażliwości słuchowej a dokuczliwością szumów i nadwrażliwości $[7,34,36,37]$. Istnieją badania wskazujące na obecność dodatkowych zmiennych wpływających na prawdopodobieństwo pojawienia się szumów usznych, takich jak: przynależność etniczna, wskaźnik masy ciała, palenie papierosów, nadciśnienie, cukrzyca, dyslipidemia, narażenie na hałas w pracy [6] czy uraz głowy [73]. Informacje te mogą okazać się bardzo przydatne w podejmowaniu działań profilaktycznych, identyfikowaniu grup docelowych oraz planowaniu odpowiednio dopasowanych terapii. Jest to szczególnie ważne, gdyż dotychczas nie został odkryty środek farmakologiczny powodujący zupełne ustąpienie tych dolegliwości.
Pojawiające się w ostatnich latach dążenia do standaryzacji metod postępowania $\mathrm{z}$ pacjentami doświadczającymi szumów usznych i nadwrażliwości słuchowej $[33,74,75]$ mają na celu stałe pogłębianie wiedzy poprzez porównanie wyników badań prowadzonych na całym świecie i współpracę naukową wyspecjalizowanych ośrodków. W piśmiennictwie polskim istnieją dwie ankiety dotyczące występowania szumów usznych i nadwrażliwości słuchowej wśród osób dorosłych. Ich zastosowanie jest ograniczone prawie wyłącznie do badań przesiewowych. Literatura anglojęzyczna zawiera kilkanaście rzetelnych kwestionariuszy oceniających różnorodne aspekty wspomnianych dolegliwości. W celu prowadzenia wiarygodnych badań zasadne wydaje się wykonanie adaptacji międzykulturowej dostępnych narzędzi do warunków i języka polskiego zgodnie z międzynarodowymi wytycznymi. Istotne braki w dostępności standaryzowanego narzędzia umożliwiającego diagnostykę i ocenę prowadzonych terapii wykazał przegląd literatury dotyczącej szumów usznych i nadwrażliwości słuchowej $\mathrm{u}$ dzieci. W związku z dużą skalą występowania tych zjawisk - od 12 do 16\% uczniów szkół podstawowych w Polsce - wskazane byłoby podjęcie próby stworzenia takiego kwestionariusza.

Publikacja powstała $w$ zwiazku $z$ realizacja projektu pn. „Zintegrowany system narzędzi do diagnostyki i telerehabilitacji schorzeń narząów zmysłów (słuchu, wzroku, mowy, równowagi, smaku, powonienia)" INNOSENSE, wspólfinansowanego przez Narodowe Centrum Badań i Rozwoju w ramach Programu STRATEGMED.

\section{Piśmiennictwo:}

1. Skarżyński H. Szumy uszne i nadwrażliwość na dźwięki. Praca zbiorowa pod red. prof. Henryka Skarżyńskiego. Warszawa: Instytut Fizjologii i Patologii Słuchu; 1998.

2. Fabijańska A, Rogowski M, Bartnik G, Skarżyński H. Epidemiology of tinnitus and hyperacusis in Poland. W: Hazell J, red. Proceeding of the 6th International Tinnitus Seminar, Cambridge, London; The Tinnitus and Hyperacusis Centre; 1999, s. $569-71$.

3. Sanchez L, Boyd C, Davis A. Prevalence and problems of tinnitus in the elderly. W: Hazell J, red. Proceedings of the 6th International Tinnitus Seminar, Cambridge. London; The Tinnitus and Hyperacusis Centre, 1999, s. 58-63.

4. Nondahl D, Cruickshanks K, Wiley T, Klein R, Klein B, Tweed T. Prevalence and 5-year incidence of tinnitus among older adults: the epidemiology of hearing loss study. J Am Acad Audiol, 2002; 13: 323-31.

5. Johansson M, Arlinger S. Prevalence of hearing impairment in a population in Sweden. Int J Audiol, 2003; 42: 18-28.

6. Shargorodsky J, Curhan GC, Farwell WR. Prevalence and characteristics of tinnitus among US adults. Am J Med, 2010; 123: 711-18.

7. McCormack A, Edmondson-Jones M, Fortnum H, Dawes P, Middleton H, Munro K, Moore D. The prevalence of tinnitus and the relationship with neuroticism in a middle-aged UK population. J Psychosom Res, 2014; 76: 56-60.

8. Raj-Koziak D, Skarżyński H, Kochanek K, Fabijańska A. Ocena częstości występowania szumów usznych u dzieci w Polsce. Otolaryngologia Polska, 2013, 67: 149-53.

9. Mills R, Cherry J. Subjective tinnitus in children with otological disorders. Int J Pediatr. Otorhinolaryngol., 1984; 7: 21-27.
10. Holgers K. Tinnitus in 7-year-old children. W: Hazell J, red. Proceedings of the $6^{\text {th }}$ International Tinnitus Seminar, Cambridge. London: The Tinnitus and Hyperacusis Centre; 1999, s. 218-19.

11. Holgers K, Juul J. The suffering of tinnitus in childhood and adolescence. Int J Audiol, 2006; 45(5): 267-72.

12. Savastano M, Marioni G, Fillipis C. Tinnitus in children without hearing impairment. Int J Pediatr Otorhinolaryngol, 2009; 73: $13-15$.

13. Chadha N, Gordon K, James A, Papsin B. Tinnitus is prevalent in children with cochlear implants. Int J Pediatr Otorhinolaryngol, 2009; 73: 671-75.

14. Rogowski M. Szumy uszne i nadwrażliwość słuchowa. W: Śliwińska-Kowalska M, red. Audiologia kliniczna. Łódź: Mediton; 2005, s. 345-51.

15. Zenner H, Pfister M. Systematic classification of tinnitus. W: Hazell J, red. Proceedings of the $6^{\text {th }}$ International Tinnitus Seminar, Cambridge. London: The Tinnitus and Hyperacusis Centre; 1999, s. 17-19.

16. Zenner H, Ernst A. Cochlear-motor, transduction and signal-transfer tinnitus models for three types of cochlear tinnitus. Eur Arch Otorhinolaryngol, 1993; 249: 447-54.

17. Baguley D. Mechanisms of tinnitus. Br Med Bull, 2002; 63: 195-212.

18. Lenarz T, Schreiner C, Snyder R, Ernst A. Neural mechanisms of tinnitus. Eur Arch Otorhinolaryngol, 1993; 249: 441-46.

19. Jastreboff P. Phantom auditory perception (tinnitus): mechanisms of generation and perception. Neurosci Res, 1990; 8: 221-54. 
20. Herraiz C. Physiopathological mechanisms in tinnitus generation and persistence. Acta Otorrinolaringol Esp, 2005; 56: 335-42.

21. Prasher D, Ceranic B, Sulkowski W, Guzek W. Objective evidence for tinnitus from spontaneous emission variability. Noise Health, 2001; 3: 61-73.

22. Bartnik G, Hawly M, Rogowski M, Raj-Koziak D, Fabijańska A, Formby C. Otoemisja produktów zniekształceń nieliniowych ślimaka oraz funkcja wejścia/wyjścia u prawidłowo słyszących pacjentów z szumem usznym i/lub nadwrażliwością słuchową. Otolaryn Pol, 2009; 63(2): 171-81.

23. Szymańska E, Bartnik G, Karpiesz L, Borawska B, Skarżyński $\mathrm{H}$, Hesse G. Terapia dźwiękowa jako terapia wspomagająca leczenie szumów usznych. Audiofonologia, 2004; 26: 185-88.

24. Jastreboff $P$, Jastreboff M. Leczenie szumów usznych oparte na modelu neurofizjologicznym. Audiofonologia, 1996; 9: 5-25.

25. Fludra M, Piełuć M, Sarnicka I. Hospitalizacja rehabilitacyjna w kryzysie związanym z doświadczaniem szumów usznych jako ramy dla interwencji psychologicznej w adaptacji do dolegliwości. Nowa Audiofonologia, 2013; 2(5): 51-54.

26. Gans J, O'Sullivan P, Bircheff V. Mindfulness based tinnitus stress reduction: pilot study. Mindfulness, 2013; 1-12.

27. Salamon E, Kim M, Beaulieu J, Stefano G. Sound therapy induceed relaxation: down regulating stress processes and pathologies. Medical Science Monitor, 2003; 9(5): 96-101.

28. Milner R, Lewandowska M, Ganc M. Niespecyficzne metody wykorzystane w terapii szumów usznych - przegląd wybranych technik. Nowa Audiofolonogia, 2014; 3(1): 20-25.

29. Martinez-Devesa P, Waddell A, Perera R, Theodoulou M. Cognitive behavioral therapy for tinnitus. Cochrane Database Syst Rev, 2007; (1): CD005233

30. Jastreboff P, Hazell J. A neurophysiological approach to tinnitus: clinical implications. Br J Audiol, 1993; 27: 7-17.

31. Távora-Vieira D, Davis P. Rehabilitation of tinnitus patients using the Neuromonics Tinnitus Treatment. Textbook of Tinnitus, 2011: 605-12.

32. Borawska B, Bartnik G, Karpiesz L, Szymańska E, Senderski A, Skarżyński H. Wstępna ocena przydatności terapii dźwiękowej u pacjentów z szumami usznymi i/lub nadwrażliwością słuchową leczonych metodą habituacji. Audiofonologia, 2004; 26: 177-79.

33. Langguth B, Goodey R, Azevedo A, Bjorne A, Cacace A, Crocetti A, Vergara R. Consensus for tinnitus patient assessment and treatment outcome measurement: Tinnitus Research Initiative meeting, Regensburg, July 2006. Prog B Res, 166: 525-36.

34. Dineen R, Doyle J, Bench J. Audiological and psychological characteristics of a group of tinnitus sufferers, prior to tinnitus management training. Br J Audiol, 1997; 31: 27-38.

35. Henry J, Wilson P. The psychometric properties of two measures of tinnitus complaint and handicap. Int Tinnitus J, 1998; 4(5): 114-21.

36. Mazurek B, Olze H, Haupt H, Szczepek A. The more the worse: The grade of noise induced hearing loss associates with the severity of tinnitus. Int J Environ Res Public Health, 2010; 7: 3071-79.

37. Seydel C, Haupt H, Olze H, Szczepek A, Mazurek B. Gender and chronic tinnitus: Differences in tinnitus-related distress depend on age and duration of tinnitus. Ear Hear, 2013; 34(5): 661-72.

38. Robinson S, MqQuaid J, Viirre E, Betzig L, Miller D, Bailey K, Harris J, Perry W. Relationship of Tinnitus Questionnaire to depressive symptoms, quality of well-being and internal focus. Int Tinnitus J, 2003; 9(2): 97-103.
39. Zeman F, Koller M, Schleckmann M, Lannguth B, Landgrebe $\mathrm{M}$. Tinnitus assessment by means of standardized self-report questionnaires: Psychometric properties of the Tinnitus Questionnaire (TQ), the Tinnitus Handicap Inventory (THI), and their short versions in an international and multi-lingual sample. Health and Quality of Life Outcomes, 2012; 10: 128

40. Savastano M. A protocol of study for tinnitus in childhood. Int J Pediatr Otorhinolaryngol, 2002; 64: 23-27.

41. Bartnik G, Fabijańska A, Jastreboff M, Rogowski M, Sienkiewicz J, Skarżyński H. Epidemiologia szumów usznych. Ankieta. Audiofonologia, 1997, 11: 209-11.

42. Kotyło P, Macheta K, Śliwińska-Kowalska M. Ocena dokuczliwości szumów usznych i ogólnego stanu zdrowia chorych z szumami usznymi przed i po krótkotrwałej rehabilitacji metodą habituacji. Otolaryngol Pol, 2009; 8(1): 23-27.

43. Goldberg D, Gater R, Sartorius N, Ustun T, Piccinelli M, Gureje $\mathrm{O} i$ wsp. The validity of two versions of the GHQ in the WHO study of mental illness in general health care. Psychol Med, 1997; 27: 191-97.

44. Kotyło P, Merecz D, Niebudek-Bogusz E, Śliwińska-Kowalska M. Program oceny i interwencji psychologicznej u pacjentów z szumami usznymi. Otolaryngol Pol, 2006; 5(4): 189-94.

45. Kuk FK1, Tyler RS, Russell D, Jordan H. The psychometric properties of a tinnitus handicap questionnaire. Ear Hear, 1990; 11: 434-45.

46. Wilson P, Henry J, Bowen M, Haralambous G. Tinnitus Reaction Questionnaire. Psychometric properties of a measure of distress associated with tinnitus. J Speech Lang Hear Res, 1991; 34: 197-201.

47. Hallam R. Manual of the Tinnitus Questionnaire. Revised and updated. London: Polpresa Press; 2008.

48. Hiller W, Goebel G. A psychometric study of complaints in chronic tinnitus. J Psychosom Res Research, 1992; 36(4): 337-48.

49. Goebel G, Hiller W. Tinnitus-Frageboten. Ein Instrument zur Erfassung von Belastung und Schweregrad bei Tinnitus (Manual). Gottingen: Hofgrefe Verlag; 1998.

50. Kam AC1, Cheung AP, Chan PY, Leung EK, Wong TK, Tong MC i wsp. Psychometric properties of a Chinese (Cantonese) version of the Tinnitus Questionnaire. Int J Audiol, 2009; 48: 568-75.

51. Newman C, Jacobson G, Spitzer J. Development of the Tinnitus Handicap Inventory. Arch Otrolaryngol Head Neck Surg, 1996; 122: 143-48.

52. Petersen Schmidt L, Niemiec Teixeira V, Dall'Igna C, Dallagnol D, Magnus Smith M. Brazilian Portuguese Language version of the "Tinnitus Handicap Inventory": Validity and Reproducibility. Rev Bras Otorrinolaringol, 2006; 72(6): 808-10.

53. Kam A, Cheung A, Chan P, Leung E, Wong T, van Hasselt C i wsp. Psychometric properties of the Chinese (Cantonese) Tinnitus Handicap Inventory. Clin Otolaryngol, 2009; 34: 309-15.

54. Aksoy S, Firat Y, Alpar R. The Tinnitus Handicap Inventory: A study of validity and reliability. Int Tinnitus J, 2007; 13(2): 94-98.

55. Zachariae R, Mirz F, Johansen L, Andersen S, Bjerring P, Pedersen B. Reliability and validity of a Danish adaptation of theTinnitus Handicap Inventory. Scand Audiol, 2000; 29: 37-43.

56. Monzani D, Genovese E, Marrara A, Gherpelli C, Pingani L, Forghieri $\mathrm{M}$ i wsp. Validity of the Italian adaptation of the Tinnitus Handicap Inventory; focus on quality of life and psychological distress in tinnitus-sufferers. Acta Otorhinolaryngol Ital, 2008; 28: 126-34. 
57. Newman C, Sandrige S, Jacobson G. Psychometric adequacy of the Tinnitus Handicap Inventory (THI) for evaluating treatment outcome. J Am Acad Audiol, 1998; 9: 153-60.

58. McCombe A, Baguley D, Coles R, McKenna L, Windle-Taylor P. Guidelines for tinnitus severity: the results of a working group commissioned by the British Association of Otolaryngologists, Head and Neck Surgeons, 1999. Clin Otolaryngol. 2001; 26(5): 388-93.

59. Beck A, Steer R, Carbin M. Psychometric properties of the Beck Depression Inventory: Twenty-five years of evaluation. Clin Psychol Rev, 1998; 8: 77-100.

60. Jacobson G, Newman C. The development of the Dizziness Handicap Inventory. Arch Otolaryngol Head Neck Surg, 1990; 116: 424-27.

61. Newman C, Weinstein B, Jacobson G, Hug G. The Hearing Handicap Inventory for Adults: psychometric adequacy and audiometric correlates. Ear Hear, 1990; 11: 176-80.

62. Wilson P, Henry J. Tinnitus Cognitions Questionnaire: Development and psychometric properties of a measure of dysfunctional cognitions associated with tinnitus. In Tinnitus J, 1998; 4(1): 23-30.

63. Henry JA, Griest S, Thielman E, McMillan G, Kaelin C, Carlson KF. Tinnitus Functional Index: Development, validation, outcomes research, and clinical application. Hear Res, 2015

64. Tyler R, Haihong J, Perreau A, Witt S, Noble W, Coelho C. Development and validation of the tinnitus primary function questionnaire. Am J Audiol, 2014; 23: 260-72.

65. Spielberger C, Grosuch R. Manual for the State-Trait Anxiety Inventory (Form Y). Palo Alto, CA: Consulting Psychologists Press; 1983.

66. Buysse D, Reynolds C, Monk T, Berman S, Kupfer D. The Pittsburgh Sleep Quality Index - A new instrument for psychiatric research. Psychiatry Res, 1989; 28: 193-213.
67. Henry J, Griest S, Zaugg T, Thielman E, Kaelin C, Galvez G i wsp. Tinnitus and Hearing Survey: A screening tool to differentiate bothersome tinnitus from hearing difficulties. Am J Audiol, 2015; 24: 66-77.

68. Jastreboff M, Jastreboff P. Questionnaires for assessment of the patients and treatment outcome. In: Hazell J, editor. Proceedings of the $6^{\text {th }}$ International Tinnitus Seminar, Cambridge. London: The Tinnitus and Hyperacusis Centre; 1999, s. $487-90$.

69. Henry J, Jastreboff M, Jastreboff P, Schechter M, Fausti S. Assesment of patients for treatment with Tinnitus Retraining Therapy. J Am Acad Audiol, 2002; 13: 523-44.

70. Henry J, Jasteboff M, Jastreboff P, Schechter M, Fausti S. Guide to conducting tinnitus retraining therapy Initial and Follow-up Interviews. J Rehabil Res Dev, 2003; 40(2): 157-78.

71. Khalfa S, Dubal S, Veuillet E, Perez-Diaz F, Jouvent R, Collet $\mathrm{L}$ Psychometric normalization of a hyperacusis questionnaire. J Otorhinolaryngol Relat Spec, 2002; 64(6): 436-42

72. Fackrell K, Fearnley C, Hoare D, Sereda M. Hyperacusis questionnaire as a tool for measuring hypersensitivity to sound in a tinnitus research population. Biomed Res Int, 2015; 2015 : 290425

73. Kreuzer P, Landgrebe M, Schlecklmann M, Staudinger S, Langguth B. Trauma-associated tinnitus: Audiological, demograpfic and clinical characteristics. PLoS One, 2012; 7(9): e45599

74. Henry J, Zaugg T, Myers P, Schecter M. The role of audiologic evaluation in progressive audiologic tinnitus management. Trends Amplif, 2008; 12(3): 170-87

75. Langguth B, Kleinjung T, Landgrebe M: Tinnitus: the complexity of standardization. Eval Health Prof, 2011; 34: 429-33. 